\title{
A Discourse Analysis Study of Graffiti at Secondary Schools in Jordan
}

\author{
Mohammad Abd Alhafeez Ali Ta'amneh \\ Taibah University, Saudi Arabia
}

\begin{abstract}
This research aims to explore the thematic meanings of graffiti written on the walls and desks at secondary public schools in the Directorate of Education for the Qasabat Irbid District during the second semester of the academic year 2020/2021. The data comprise 207 written graffiti taken from different locations. Braun and Clarke's (2006) Thematic Analysis and Fairclough's (1995) Critical Discourse Analysis are adopted to account for the data thematically and linguistically. The findings of the study show that the qualitative and quantitative data fall into three main discourse themes: Religious, Political, and Emotional. Each one has been classified into subcategories accordingly. The results also show that the highest percentage of the discourse theme domains is related to the emotional one which constitutes the half of data. The lexical features indicate that the language of the graffiti is simple. Yet, it presents a complete thought. Languages and language variations are also identified.
\end{abstract}

Index Terms - critical discourse analysis, Graffiti, linguistic, Graffiti types, lexical features

\section{INTRODUCTION}

People use coded languages to communicate between themselves. The message of such languages should be mutually understood. Otherwise, it will be a recipe for chaos. That is to say, neither the sender nor the receiver will comprehend the message and the degree of misunderstanding will be dramatically spotted out. Miller (1963, p.10) notes that when people communicate, they move the information from one place to another. Therefore, the information should be encoded in a set of symbols. He adds that the code "consists of spoken sounds, of written squiggles or whatever other set of symbols is convenient."

Graffiti, as a means of communication, can be dated back to a pre-historic era since different kinds of pictures and symbols were found on the walls or surface of caves where ancient nations established their homes. Tracy (2005, p. 22) views this phenomenon as an important one and regards it as "freedom of expressions" whose writers are often anonymous. Scholars around the world investigate the content of this kind of writing and the motivational factors that trigger using graffiti as a means of interaction between individuals of a particular society. Farina (2014, p.48) adopts Raymonda's (2008) term and views graffiti as "a second diary book" to refer to graffiti where people' voices are represented in either public or private places to convey their anger, instantons thought, love, declaration, political proclamation, outcry, etc." Therefore, the present study sheds the light on the thematic purposes identified on the walls and desks at secondary public schools in the Directorate of Education for the Qasabat Irbid District. Additionally, it tends to explore how students express their feelings and thoughts which will be discussed in details in the next section.

\section{HISTORICAL BACKGROUND OF THE STUDY}

The language provides the access to other's minds. It also reflects their implicit or explicit thoughts and attitudes towards the diversity and the domains of life. The relationships between language and its social, political or religious implications are the center of linguists' attention. Sociolinguists, for instance, affirm the relationships between language and society. Warndhugh (2006, p.10) points that "there are several possible relationships between language and society. One is that social structure may either influence or determine linguists' structure and/or behavior." The use of a certain expression may be affected by the social norm or class. Thus, it directs and determines people to use a particular use of language.

\section{Statement of THE Problem}

Trahan (2011) maintains that graffiti has been received particular attention throughout history since it is a cultural phenomenon. Yet, a researcher has to explore how the characteristics of the medium itself influence the graffiti for which it serves as a backdrop. The present study tends to discover the thematic analysis of the used expressions and how graffiti in different contexts serves to air people's attitudes, beliefs, concerns, interest, and feelings about their surroundings. To the best knowledge of the researcher, there are few studies done on graffiti at schools. Therefore, conducting an analysis of this graffiti may bridge the research gap in particular and the types of graffiti in general. 
This study derives its importance from the fact that it offers an analysis of the written discourse pictured as graffiti at secondary public schools in the Directorate of Education for the Qasabat Irbid District. In fact, the study is significant because it is hoped that this study may offer a valued source of data to the field of linguistics in particular and other fields of study in general such as politics, sociology, psychology, and religions. It is also expected for the study to explore the themes of such graffiti and inspect the motivational factors that produce people's writings. Furthermore, the study will predictably account for the language of the graffiti concerning society as a prerequisite of Critical Discourse Analysis.

\section{QUESTIONS OF THE STUDY}

Using the post-structuralist model of discourse analysis framework, the study attempts to answer the following questions:

1. What thematic contents do the graffiti-writings serve?

2. What are the languages, language variations, lexical and syntactic features that constitute the language of graffitiwritings?

\section{LITERATURE REVIEW}

\section{A. Theoretical Background}

The etymology of graffiti originally came from the Greek word "gaphein" meaning "to write" and it is the plural form of the Italian word "graffito" to mean drawing, scratched, and inscription. Chiluwa (2008, p.274) refers to graffiti as "any form of writing or images on the walls or surfaces of public buildings, parks, toilets, buses or trains, usually bearing some political or sexual contents". Crystal (1979, p.181) affirms this and describes graffiti as any type of public marking that can be seen in the forms of "simple written words to elaborate wall paintings". That is to say, graffiti is considered as a means of communication written in public places or anywhere to deliver a message without any social, political or religious strains that prevent people from doing so. To elaborate this, the intended message of such writings underlines a thematic purpose and reflects one's identity, ideology, thoughts and beliefs about a particular topic.

Scholars hold different attitudes towards graffiti. On the one hand, some of those scholars as Nwoye (1993) refer to them as a means of strike, undesirable annoyance, a sign of rebellion against authorities and a form of defacement and manifestation of vandalism. On the other hand, Obeng (2000) views graffiti as a means of "egalitarian" to express and offer the chance to the marginalized people and help them to "speak the unspeakable". Other scholars also consider graffiti as a valuable source of viewpoints and thoughts of others toward a certain issue. Yeike (2003), for example, maintains that graffiti is "a source of information about significant social issues and problems" (Cited in Al-Khawaldeh et al., 2017, p. 31). In other words, the message revealed from such writings may affect politician's points of view, for instance, and direct their attention toward a certain problem to be solved. According to Abu Eissa and Rababah (2020, p. 201) "Graffiti has value and importance in conveying certain messages as means of communication. It expresses individuals' sense of freedom or revolution they may feel or want to show". Yet, there is another argument hold by scholars like Basthomi (2009) that perceives graffiti as "dominant rhetoric" which blocks the second party to respond positively or negatively. Overall, even though graffiti is considered as manifestation of vandalism by some scholars. It still served as means of communication that infers a message and offers the chance to others to respond or stimulate them to take an action.

The phenomenon of graffiti was the center of attention to many scholars from various disciplines. Cultural analysis such as Bushnell (1990) views graffiti as an important source of information that helps in evaluating the undercurrent developments within a specific cultural group. Psychological analysis like Abel and Buckly (1977) examine the motivational factors that stimulate individuals to produce such writings. Historical analysis such as Shillington (1977) shed the lights on graffiti to explore and understand the history of a certain culture.

Linguists like Gross et al (1997) describe graffiti as a "linguistic phenomenon" that involves both "form and content" and makes use of discourse to mean something other than itself. Because graffiti writings, as mentioned earlier, contain a communicative message and donate a meaning determined by social or political factors, their "forms and contents" can be linguistically investigated in general and from discourse analysis in particular.

Discourse analysis does not only study the language use "beyond the sentence boundary" as suggested by Brown and Yule (1983), but it also accounts for the "naturally occurring language use". Thus, linguists who study graffiti do not only examine the structure of the patterns and their implicit or explicit meaning, but they pay too much attention to the use of that language as a social practice in a particular society.

Fairclough (1989, p.18) proposes that "language is a part of society" and language itself is "a social process" (ibid., p.19). He also argues that language and society are externally and internally related. Therefore, studying the language of graffiti cannot be fully analyzed where the social norms and strains are isolated. Therefore, the discourse of graffiti is seen as a social interaction process where the production of the language of graffiti is affected by external and/or internal factors.

To analyze a certain discourse, Fairclough (1995) also suggests that there should be interrelated processes that are tied to three dimensions, which are: 
1. The object of analysis (including verbal, visual, or verbal and visual texts).

2. The process by which the object is produced and received (writing, speaking, designing and reading, listening, viewing) by human subjects.

3. The socio-historical conditions that govern these processes.

To restate, when a linguist tries to account for the "form and content" of any object, graffiti as an example, he/she has to consider the internal process by which that object is produced and then received and the external factors that determine such a process. (i.e. the imposed impacts of both society and history on producing and receiving that object).

Applying the three mentioned processes to consider graffiti as a discourse starts from the text analysis itself which is referred to as a "description" then moving to process analysis which is "interpretation" and finally explaining the sociohistorical conditions that direct the producing and receiving that discourse. Janks (1997, p.329) confirms the usefulness of this approach when analyzing as a text. She points out that this method of analysis "provides multiple points of analytic entry" since it accounts for the tied choices (social and historical) that make up the text in the process of production and reception.

\section{B. Empirical Studies}

One of the first studies of graffiti from a linguistic approach can be traced back to Girder (1975). He presents graffiti as "a mode of linguistic communication within a community setting and their ramification." In his study, he investigated the cultural linguistic functions of "con safos" graffiti within the Mexican-American community.

Some scholars tend to classify the phenomenon of graffiti into two types: public and private (Emmison and Smith, 2002). As opposed to private graffiti, Reinser (1971) defines public graffiti by explaining that they are done in open areas where there is a greater possibility for the writer to be seen and known (Cited in El-Nashal and Nayef , 2016, p.228). Gadsby (1995) identifies six different types of graffiti which are latrinalia (restroom graffiti as proposed by Dundes (1966), public, folk, epigraphy, historical, tags and humorous. In his study to graffiti in the main library of four different universities in the United States, Dombrowski (2011) finds out the quantitative analysis of the data reveals that insult and remarks about advice, classes, love, the surroundings, school and oneself and sex are the most common ones found in the library.

In a way of identifying the communicative strategies employed in graffiti writing and the influence of learning the language of graffiti on the English language, Mwangi (2012) finds out that students used varied communicative strategies like humor, symbolism, irony, short forms, acronyms, and abbreviation in their graffiti writings. In a study done by Raymond (2008), the researcher analyzes the kinds of register, the functions, and the styles of graffiti art found in Surakarta. The results reveal that there are three types of register that can be classified by their class of word which are noun, adjective and verb. Additionally, seven functions of graffiti art pictures are also found in Surakarta community.

In a way to explore the linguistic aspects in Iranian's graffiti, Shivanda et al.(2015) apply Hall's (1980) fifteen process in defining linguistic features on graffiti. The results show that there are clear linguistic aspects in the collected graffiti. Dialogues were the most frequent linguistic aspect while questions of no answers and punning on re-division of words were the least frequent ones (Cited in Al-Khawaldeh et al., 2017).

In Egypt, El-Nashar and Nayef (2016) follow Fairclough's (1995) Post-Structuralist model of discourse analysis to account for vehicle graffiti on the roads of Egypt. The study is meant to examine the various domains of vehicle graffiti by studying the themes in accordance with the language in use. Lexical features of graffiti and language variations were also tackled. Results show that the religious expressions compose more than the half of data.

A more recent study done in Jordan, Al-Khawaldeh et al.(2017) adopt also the same model of Fairclough's (1995) Critical Discourse Analysis and Braun and Clark's (2006) models to investigate the thematic analysis of the graffiti contents and the communicative features of the graffiti writings on two governmental universities. The data reveals that the linguistic features of these graffiti are simplicity and variation. Moreover, different communicative functions were identified in the language of graffiti such as personal, social, national, religious, political and taboos matters.

It is clear-cut that graffiti writings have been tackled from different domains of studies. That is to say, studies have been appealed to many disciplines such as cultural, psychological, historical and linguistic ones. Researchers of such disciplines account for the data of the graffiti from different angles. Yet, they in general were after analyzing the types of graffiti by classifying them into sub-classifications.

In linguistics, researchers dealt with the corpus of graffiti by adopting approaches like Fairclough's (1995) model of Critical Discourse Analysis and Braun and Clark's (2006) models of Thematic Analysis to investigate both "content and form" of the graffiti. They analyze the various discourse domains that the language of graffiti falls into and then account for the language in terms of structure, discourse markers and other linguistic features concerning domains of life that may affect its use or impose a kind of restriction on it. After reviewing the literature of graffiti and to the best knowledge of the researcher, the present study sheds the light on graffiti at secondary public schools in the Directorate of Education for the Qasabat Irbid District in Jordan. In fact, the study derives its importance from the fact that it will explore the various discourse domains of graffiti through thematic classification to these graffiti writings and discover the lexical and syntactic features and language variations.

\section{Data Collection AND Methodology}


The population of the study included all the written graffiti (there are graffiti of pictorial and symbols forms. For the purpose of this study, the written graffiti will be only investigated) found in the walls and desks at secondary public schools in the Directorate of Education for the Qasabat Irbid District in Jordan. The sample of the study consisted of 207 written sentences/ phrases/ words in both the Arabic and English languages displayed on walls and desks to represent different aspects and perspectives of language. This is a corpus-based discourse analysis study. Discourses are drawn from graffiti written on the walls and desks. The researcher visited most of these places. For each place, pictures were taken and then classified into a set of categories according to the theme they serve or donate. There were two languages (Arabic and English) used in the graffiti. The norms of the Arabic language were also classified into standard and colloquial. The degree of formality and matters of gender graffiti were also identified.

\section{DATA ANALYSIS}

Data were qualitatively and quantitatively analyzed. The number of written graffiti was counted. Frequencies and percentages of each theme derived from those writings were also calculated and tabulated. In fact, the resultant themes were reviewed by a specialist in the Arabic language to ensure the validity and reliability of the study and the whole set of data goes under the selected theme. This method, as (Braun and Clarke 2006, 77) noted, can "potentially provide a rich and detailed, yet a complex account of data, and make their examination easier." (Cited in Al-Khawaldeh et al., 2017).

The original writings "the raw data" were kept as they are without any intervention. The drawn Arabic sentences used in this study are translated into English. The researcher translates all of them except those cited from the Holy Quran and Hadeeth (the Prophet's Sayings). Ali's (1975) translation of the Glorious Quran is used as well as- Sunnah for Hadeeth translation. Spelling and grammar mistakes, for example, were not corrected. Then, the language of such inscriptions was analyzed in terms of linguistic features such as the lexical and syntactic ones.

To account for the data linguistically and thematically, the researcher adopted the methodology employed by Fairclough's (1995) Critical Discourse Analysis, Braun and Clarke's (2006) Thematic Analysis, El-Nashar and Nayef (2016), and Al-Khawaldeh etal. (2017). Fairclough (1995) argues that when analyzing a text, various elements like language function, lexicon, grammar, coherence and cohesion, and text structure should be taken into consideration. He also advises extending the analysis to consider the language as a "social practice" that influences or shapes the language. Consequently, the speaker's intention as a product will be clearly identified. Thus, using this approach will offer explanations to Elements that constitute the language of the chosen graffiti.

Thematic analysis widely uses the qualitative analysis method within Psychology. Braun and Clarke (2006) analyze the content of the writing (i.e graffiti) by collecting similar thematic codes or patterns to applicable/ relevant groups of meaning. Hence, following this analysis, the implicit and explicit meanings of such writing can be categorized accordingly. That is to say, the codes of frequencies and occurrences of a particular group of messages can be traced and then common themes can be determined.

\section{VARIABLES OF THE STUDY}

The study has independent and dependent variables. The independent ones are represented in the categorized and sub-categorized themes while dependent variables will be the used language (Arabic or English), the norm (standard or colloquial), and the degree of formality (formal or informal).

\section{Results}

The results of the questions will be answered through statistical analysis. Generally speaking, the presentation of this chapter starts with the questions followed by some comments about the result of each question. Concerning the first question (What thematic contents do the graffiti-writings serve?), the qualitative analysis of the collected data of graffiti being written on the walls and desks shows that they serve different themes. Such themes were categorized based on the meaning of the contents. Each theme then was also sub-categorized based on codes of meanings. Firstly, the overall percentages of all themes will be presented in figure 1. Subsequently, the other sub-categorizations of each theme will be presented in figures 2,3 , and 4 .

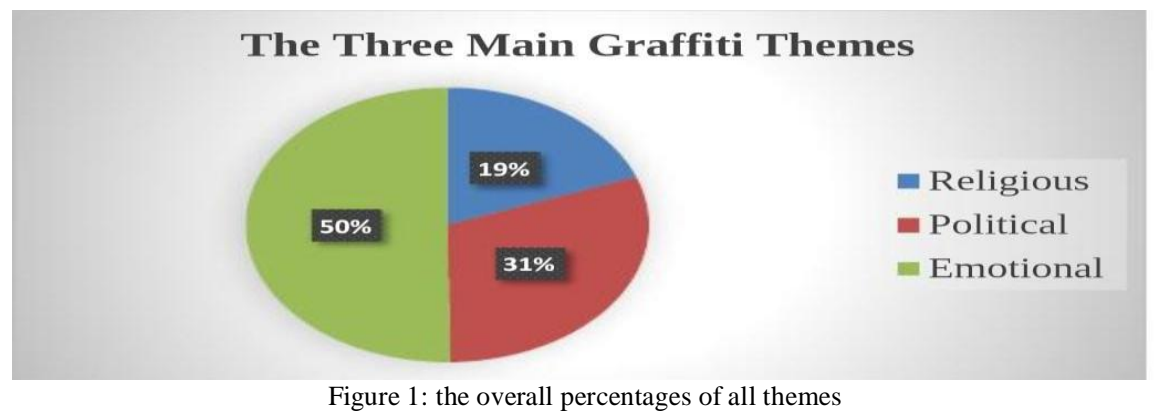

Figure 1: the overall percentages of all themes 
Comparing the themes expressed in graffiti yields the following statistical results. It is obvious that the highest percentage of these discourse theme domains is related to the emotional theme. It accounts for half of the overall number of language theme located on the walls. It is considered the most frequently occurring theme in the quantitative data. There were (104) occurrences to this category and its subcategories. The Political theme ranks second with a percentage of (31\%). By contrast, the religious theme is the least frequent one with a percentage of (19\%) as it constitutes the lowest percentage of the overall themes. Only (40) occurrences of data were recorded for this theme accordingly.

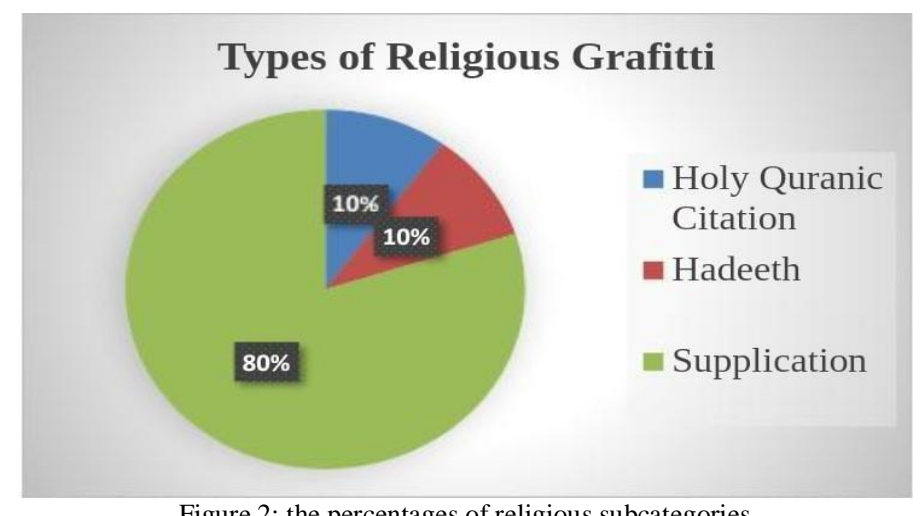

Figure 2: the percentages of religious subcategories

After examining figure 2, it is clear-cut that "supplication" forms the dominant percentage of (80\%) as against the other two-subcategories. The results show that the other two types of religious theme namely the "Holy Quranic and Hadeeth (Prophet Mohammad's sayings Peace be upon him). They equally accounted for (10\%) of the overall discourse theme.

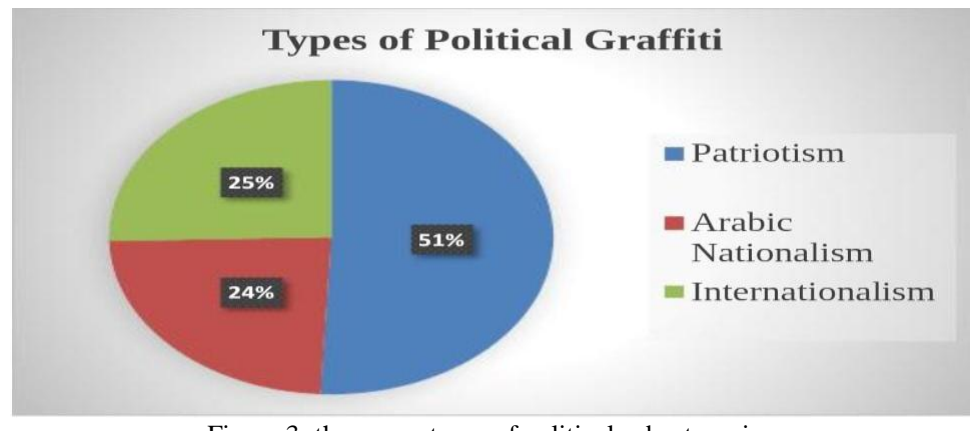

Figure 3: the percentages of political subcategories

Based on the previous figure (3), the data revealed that students' political views of patriotism shaped half of the overall percentages of the political graffiti. There were (32) occurrences as against (16) of "internationalism" and (15) of "Arabic Nationalism" instances of the other two halves of types of this graffiti which both of them constitute the other half respectively.

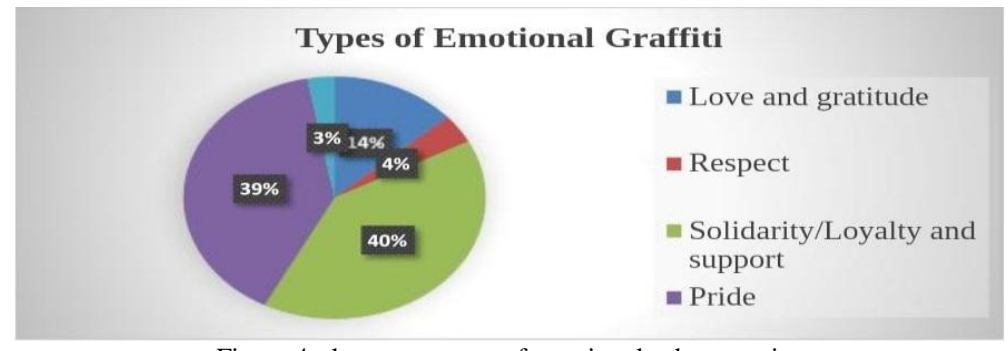

Figure 4: the percentages of emotional subcategories

The discourse domain that constitutes the first and largest number of occurrences in the data is the emotional expressions graffiti scoring (104) occurrences. The data analysis of "Solidarity/ Loyalty and Support" as the main subcategory displays (40\%) of the data under investigation and accounts for the first rank among the five types of "Emotional Graffiti". Identically with a slight statistical difference, "Pride" ranked second with a number of (41) instances of occurrence.

"Love and Gratitude" comes in the third rank in this type of graffiti. It has been found that (14\%) of "Emotional Graffiti fall under this domain. People tend to be emotionally more with using expressions of support and pride to 
express their love and gratitude. The last two types of this domain include "Respect" and "Advice". They score (4\% and $3 \%)$ respectively. Predictably, Showing respect and offering pieces of advice are not the center of attention to the students.

To answer the second question (What are the languages, language variations, lexical and syntactic features that constitute the language of graffiti-writings?), the researcher inspected the instances where the Arabic and English languages were used when writing graffiti. Similarly, Modern Standard Arabic and colloquial Arabic were also examined. Numbers of nominal and verbal sentences are also drawn out and calculated in table number 1. Regarding the lexical and syntactic features, they will be fairly discussed in the next coming section.

TABLE 1

THE LiNGUISTIC OCCURRENCES AND PERCENTAGES OF GRAFFITI DATA

\begin{tabular}{|l|l|l|l|l|l|l|l|}
\hline \multirow{2}{*}{ No } & \multirow{2}{*}{} & Language & Norm & \multicolumn{2}{l|}{ Sentence Type } \\
\cline { 2 - 8 } & Theme & Arabic & English & Standard & Colloquial & Nominal & Verbal \\
\hline A & Religious & 39 & 1 & 23 & 16 & 24 \\
\hline B & Political & 40 & 23 & 26 & 12 & 27 \\
\hline C & Emotional & 87 & 17 & 39 & 57 & 10 \\
\hline
\end{tabular}

Through a close look at Table 1, the two dominant languages used in the students' writing are Arabic and English. The dominant number of occurrences is clearly detected in the Arabic language of all the three main themes. The percentages ranged from the highest (97\%) in the writing of religious graffiti to the lowest of (63\%) in the political one. By contrast, The English language is frequently used in the political domain with a number of occurrences account for (23) out of (63) in the same domain. Only (2.5\%) of students use religious graffiti to express their supplications. A reasonable justification comes from the fact that all students are Muslims and speak the Arabic language.

The language variation is generally classified into two norms: the modern standard and colloquial Arabic. It is clear from the data that people use standard Arabic the most when they use religious expressions. The standard Arabic, particularly in this domain, constitutes $(57.5 \%)$ as the highest percentage. Comparing this to colloquial Arabic, people are likely to use this kind of variation when expressing their emotional languages. It accounts for (46.2\%) of the overall percentages in that theme.

Regarding the sentence types, nominal and verbal sentences are counted after being examined by a specialist in Arabic. The data shows that in the "Emotional theme" (54.8\%) of sentences were nominal in their types. This theme scores the highest occurrences of (57) against (104) of the total occurrences. By contrast, the verbal sentences score the least frequent number of occurrences in the "political" domain of graffiti. Linguistically speaking, nominal sentences tend to be more intimate as they show a degree of informality between interlocutors.

\section{DISCUSSION}

The purpose of this study was to investigate the discourse themes of graffiti in secondary public schools in the Directorate of Education for the Qasabat Irbid District during the academic year 2020\2021 using mainly Braun and Clarke's (2006) Thematic Analysis and Fairclough's (1995) Critical Discourse Analysis. In this section, the discussion of the two main questions of the study, conclusion and recommendation for future research will be intensively discussed.

Concerning the first question (What thematic contents do the graffiti-writings serve?), the data analysis reveals that there are three main themes detected in the graffiti. Examining the corpus of the data also indicates that there are specific types for each theme. Discussion of each category and subcategory of each theme will be presented in this section as follows:

\section{A. Religious Themes}

As shown in figure 1, the Religious theme accounts for (19\%) of the overall themes. This theme consists of three main types namely: Holy Quranic citation, Hadeeth , and supplication. The vast majority of the used expressions fall under "supplication". An explanation for this result comes from the fact that students ask for God's mercy, help and support.

Expressions like "اللهم احفظ الأردن والملك عبدالله" , "الله يحفظ الأردن " May God protect Jordan: May God take care of Jordan and our King Abdullah" are the most visible ones on the walls. This asserts that people choose to supplicate or say "dua" as a form of worship as stated in the Holy Qur'an and Hadeeth. Students value the use of supplication as it relates them to the essence of Islam as the prophet Mohammad Says. The other two types of the religious themes are subcategorized into "Holy Quranic" and "Hadeeth (the prophet's Sayings). The number of occurrences for these types was equal in number (only 4). Graffitists cite some verses from the Holy Quran to reaffirm their faiths. The following verse (ayah) is cited from Al-Imran "The House of Imran" number (103) و واعتصموا بحبل الله جميعا و لا تفرقوا)"And hold fast, all together, by the rope which Allah (stretches out for you), and be not divided among yourselves".

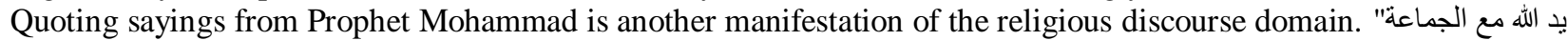
" " Allah's Hand is with the jama'ah (Muslims' community)" (This Hadeeth is narrated by Ibn Abbas, Jami`at-Tirmidhi, 
Book 33, Hadith 9). The use of this Hadeeth is to emphasize that a Muslim should not split away in the Muslim's community or otherwise he/she will be set on the fire on Judgment Day. Table (2) presents other examples for the three types of religious graffiti displayed on walls.

TABLE 2

EXAMPLES OF RELIGIOUS THEME

\begin{tabular}{|l|l|l|}
\hline Religious themes & Examples & English Translation \\
\hline Holy Quranic & "and fall into no disputes, lest ye lose heart and your \\
power depart;"
\end{tabular}

\section{B. Political Themes}

Figure (3) demonstrates that there are three types of political graffiti. The majority of students use political expressions that donate patriotism. As previously explained, this type accounts for $(51 \%)$ of the overall percentages of these political themes. Jordanian students have a great sense of belonging, attachment, and responsibility toward their وان صار ما صار نبقى للأردن , "الأردن حلوة وأجمل لوحة في عيني" "العز عزك با الأردن" country and leadership. Expressions like "الأوفياء "Glory is the glory of Jordan", "Jordan is beautiful and it is the most beautiful painting I can see", "whatever happens, we will be very loyal to our country-Jordan" donate patriotic feelings as it is well-rooted in Jordanian's heart. As a kind of dedication, Jordanian students find patriotic expressions a noticeable way to express their loyalty to their nation.

\section{Emotional Themes}

Emotional languages constitute the highest and the most frequent ones of all themes. There are five main subcategories that fall under the emotional theme namely: love and gratitude, showing respect, solidarity/ loyalty and support, pride and advice. Showing respect and offering advice have the lowest percentages of (4\%) and (3\%) respectively. Students choose to express other kinds of feeling since the last two types are already included in the major trends of themes. People also quote some words of the king as an indicator to show their respect and attitude to the king's political position for example: "نحن قوم نلتزم بمبادئنا وقيمنا "We are committed to our principles and values". Offering advice was the least frequent in number at all with only one instance in Arabic and two instances in English.

On the contrary, graffiti of solidarity/ loyalty and support, and pride ranked the highest percentages of all types of emotional themes. The political conditions trigger people to choose sentences full of solidarity/loyalty and support. Graffiti writings like, " تحت أمرك" , "نحن جنودك "We are under your command" and "We are your soldiers" are expected ones in this political crises. Inscriptions that donate pride are also noticeable. Table (2) presents other examples for the five types of emotional graffiti.

TABLE 3

EXAMPLES OF EMOTIONAL THEME

\begin{tabular}{|c|c|c|}
\hline Emotional Type & Examples & English Translation \\
\hline \multirow[t]{3}{*}{ Love and gratitude } & حبيبي عبد الله & My love is Abdullah. \\
\hline & شعب الأردن في قلب عبد الله & People of Jordan are in Abdulla's heart. \\
\hline & نحبك يا عبد الله & We love you Abdullah. \\
\hline \multirow[t]{2}{*}{ Respect } & عنوان الحق ووجه الحقيقة & You are the address of rightness and the face of truth. \\
\hline & إن كان لناوطن فهو أنت و ان كان للك شعب فهو نحن & You are our shelter; we are your \\
\hline $\begin{array}{l}\text { Solidarity/Loyalty and } \\
\text { support }\end{array}$ & روح وحنا خلفكا & Go ahead! We are following your steps. \\
\hline \multirow[t]{3}{*}{ Pride } & الأردن أولا & Jordan first \\
\hline & عبد الله الفخر والعز و الوطن يا أغلى وطن & $\begin{array}{l}\text { Abdullah, you are the source of pride, glory and } \\
\text { protection and you are the precious. }\end{array}$ \\
\hline & ابشروا بالعز و الخير & Take it as a promise of life of prominence and goodness. \\
\hline Advice & كن قويا نحن أردنيون & Stay strong we are Jordanian \\
\hline
\end{tabular}


In keeping up with the findings of the present study, the results match the findings of Al-Khawaldeh et al. (2017), ElNashar and Nayef (2016), and Farnia (2014) in that they view graffiti as a mood of communication through which people express their views freely. Additionally, the study is in line with the previous studies in that the contents of the graffiti carry implicit and explicit meanings and themes (religious, political, and emotional). The findings are also in agreement with the findings of Farinia (2014) and Al-Khawaldeh et al. (2017) who find that graffiti is an act that reflects people's attitudes and concerns of common present-day issues.

Regarding Question two (What are the languages, language variations, lexical and syntactic features that constitute the language of graffiti-writings?, the data reveals that both Arabic and English are used apparently. Yet, the dominant language is Arabic since the current study has been carried out in an Arabic country. Language variation is spotted out by analyzing the data. The graffiti of writings reveals that both Modern Standard Arabic (MSA) and colloquial (another manifestation of MSA) are used. The MSA is used heavily in religious themes. In fact, this can be explained by the fact people cited and quoted the original texts from the Holy Quran and the prophet's sayings. They also used MSA when they supplicate and ask God to help them in different areas. The degree of formality also increases as they address King "Abdallah as seen in this example " "حفظكم الله جلالة الملك "May God protect you, His Majesty". The attached morpheme" "m" in the word "حفظكم" shows a certain degree of formality so that the social distance between the address and addressee is preserved. It is also found that Jordanian dialect and other forms of Arabic dialects are captured in the forms of their writing. Another point to be raised here is that the excessive use of vernacular Arabic in the writing of graffiti affirms the fact that using colloquial dialects is related to the feeling of intimacy and closeness between interlocutors.

Regarding the lexical features of the graffiti, it is shown from the data that there is a kind of overlap between the contents of the themes. Some sentences share a partial or almost the same meaning. This finding is in correspondence with El-Nashar and Nayef (2016). Yet, some detected features distinguish one sub-category from another. For example, the use of "دام in "دام عزك ياوطني الغالي "' " May God sustain the prominence of this beloved country" has implicit/covert agent who is almighty God so that the sentence reads in MSA "أدام الله عزك يا وطني الغالي" " . The overlapping between the sub-categories of supplication and the political feeling of patriotism can be clearly seen. Yet, the researcher prefers to categorize this graffiti under the later one since the feeling is more evident as patriotism. The syntactic features of the graffiti of all themes can be discussed as accounting for sentence patterns and the grammaticality of the sentences.

There are nominal and verbal sentences identified in the corpus of data. The nominal ones weigh the verbal in the number of occurrences. A clear explanation to this can be understood by the fact that "verbal sentence is used more for the narration of events because it organizes sentences around verbs, and the nominal sentence is used when there are particular topics under discussion because it sets up the topics as the head of the sentence" as stated by Brustad et al. (2010). Stocker et al. (1972) viewed graffiti as an indicator that reflects people's social attitudes in a particular community. People's attitudes using the nominal sentences here is affected by the social practices of people since they prefer to use nominal ones especially if there is a kind of discussion and the focus is on the doer of action rather than the event itself.

The graffiti writings are inscribed in full sentences that express full thoughts. Yet, there are not typical grammatical sentences in both Arabic and English. For example, in the following sentence, it is used as the accusative case that triggers the sentence to be ungrammatical since it functions as the noun of "ظل " which should be in the nominative one: "Abdullah will always be as the crown". Spelling mistakes are found and no punctuation marks were used in all of the occurrences of the two languages. Another remark observed in the data that the majority of the sentences are simple. Only two occurrences of conditional and relative clauses are examined. Only one occurrence of dialogue as a literary verse. The same findings were mentioned by Al-Khawaldeh et al. (2017, p. 39) "..as simple or syntactically less complex and void of punctuation marks."

\section{Conclusion}

The study investigates the graffiti writings and their thematic meanings they serve. Linguistic features are also examined using Fairclough's (1995) model of Critical Discourse Analysis. The analysis asserts that graffiti is "a linguistic phenomenon" that can be analyzed in terms of "form and content" The contents of the graffiti suggest different thematic meanings as they are grouped into three main religious, political and emotional discourse domains where the latter one accounts for the highest number of occurrences and percentages. Then, applying Braun and Clarke's (2006) Thematic Analysis, certain codes are detected which helps the researcher to regroup the inscription into subcategorization namely: Holy Quranic citation, Hadeeth, supplication, patriotism, Arabic Nationalism, Internationalism, Love and Gratitude, solidarity/loyalty and support, pride, and advice.

The syntactic features of the study reveal both the Arabic and English languages are used in the inscriptions of graffiti writings. The dominant language is Arabic. MSA and colloquial dialects are also visible in their writings where the number of occurrences of the colloquial dialects is more. The sentences are simple of a complete thought. The nominal sentences are found to be more than the verbal ones.

\section{RECOMmEndations AND EdUCATIONAL SUGGESTIONS}


Based on the findings of the study, the researcher recommends the following:

1. It is recommended that the graffiti is not only considered as a platform of communication, but it also reflects students' thoughts governed by norms of society.

2. To avoid vandalism of other's property without permission, it is advisable to install legal billboards in special places at schools and educational institutions so that graffitists can express their thoughts freely.

\section{SUGGESTION FOR FUTURE RESEARCH}

The findings of this study are limited to the written graffiti on the desks and walls of the secondary public schools in the Directorate of Education for the Qasabat Irbid District Irbid Governorate in Jordan during the second semester of the academic year 2020/2021 that display students' thoughts and opinions. Therefore, the findings cannot be generalized to other types of graffiti displayed in Jordan and other countries.

For future research, it might be valuable to repeat the study with larger samples of graffiti data in general or to other types of graffiti: vehicles, internet blogs and hatch tags as examples. The data can also be analyzed using different linguistic domains or approaches, as this will enrich the literature of linguistics in particular and other scholarly disciplines in general.

\section{REFERENCES}

[1] Abel, Ernest L. \& Buckley, Barbara E. (1977). The Handwriting on the Wall: Toward a Sociology and Psychology of Graffiti. Westport, Conn: Greenwood Press.

[2] Abu Eissa, F., \& Rababah, L. (2020). Exploring Types of Graffiti at Jadara University in Jordan. Journal for the Study of English Linguistics, 8(1), 200-215.

[3] Ali, Y. (1975). The Glorious Quran: Translation and commentary. Eduright4all.

[4] Al-Khawaldeh, N. Khawaldeh, I., Bani-Khair, B. \& Al-Khawaldeh, A. (2017). An Exploration of Graffiti on University's Walls: A Corpus-Based Discourse Analysis Study. Indonesian Journal of Applied Linguistics, 7 (1), 29-42.

[5] Basthomi, Y. (2009). Truck graffiti: The rhetoric of emulation. Dialogue Analysis XI. 217-228

[6] Braun, V., and Clarke, V. (2006). Using thematic analysis in psychology. Qualitative Research in Psychology, 3(2), 77-101.

[7] Brown, Gillian, and George Yule. (1983). Discourse Analysis. Cambridge: Cambridge University Press.

[8] Brustad, K., Al-Batal, M., and Al-Tonsi, A. (2010). Al-Kitaab fii Ta'allum al-'Arabiyya with DVDs: A Textbook for Beginning Arabic, Part One Second Edition (Arabic Edition).Georgetown University Press.

[9] Bushnell, D. (1990). Input, process, output: A model for evaluating training. Training and Development Journal, 44(3), 41-43.

[10] Chiluwa,I. (2008). Religious vehicle stickers in Nigeria: A discourse of identity, faith and social vision. Discourse \& Communication, 2(4), 371-387.

[11] Crystal, D. (1997). The Cambridge Encyclopedia of Language, London: Cambridge University Press.

[12] Dombrowski, Q. (2011). Walls that talk: Thematic variation in University library graffiti. Journal of the Chicago Colloquium on Digital Humanities and Computer Science, 1(3), 1-13.

[13] Dundes, A. (1966). Here I Sit: A Study of American Latrinalia. Kroeber Anthropological Society Paper, 34, 91-105.

[14] El-Nashar, M. \& Nayef, H. (2016). Discourse on the go: Thematic analysis of vehicle graffiti on the roads of Egypt. Advances in Language and Literary Studies, 7(5), 227-239.

[15] Emmison, M., and Smith, P. (2000). Researching the visual: Images, objects, contexts and interactions in social and cultural inquiry. London: Sage Publications.

[16] Fairclough, N. (1989). Language and power. London: Longman.

[17] Fairclough, N. (1995). Media discourse. London: Edward Arnold.

[18] Farnia, M. (2014). A thematic analysis of graffiti on the university classroom walls: A case of Iran. International Journal of Applied Linguistics and English Literature, 3(3), 48-57.

[19] Gadsby, J. M. (1995). Looking at the writing on the wall: A critical review and taxonomy of graffiti texts. Unpublished MA thesis. Boston: USA.

[20] George Armitage, M. (1963). Language and communication. New York: McGraw-Hill.

[21] Grider, S. (1975). Con Safos: Mexican-Americans, Names and Graffiti. Journal of American Folklore, 88(348), $132-142$.

[22] Gross, D. D., Walkosz, B., \& Gross, T. D. (1997). Language Boundaries and Discourse Stability "Tagging" as a Form of Graffiti Spanning International Borders. Et Cetra, 54, 275-285.

[23] Hilary, J. (1997). Critical Discourse Analysis as a Research Tool. Discourse: Studies in the Cultural Politics of Education 18(3), 329-342.

[24] Janks, H. (1997). Critical Discourse Analysis as a Research Tool. Discourse Studies in the Cultural Politics of Education, 18(3), $329-342$

[25] Miller, Henry. (1963). Transaction: Dewey's Last Contribution to The Theory of Learning. Educational Theory, 13(1), 13-28.

[26] Mwangi, F. G. (2012). Graffiti Writing and Its Likely Influence on English Language Learning in Selected Secondary Schools in the Larger Laikipia East District, Laikipia County. (Unpublished doctoral dissertation). Kenyatta University, Kenya.

[27] Mwangi, F. G. (2012). Graffiti Writing and Its Likely Influence on English Language Learning in Selected Secondary Schools in the Larger Laikipia East District, Laikipia County. (Unpublished doctoral dissertation). Kenyatta University, Kenya.

[28] Nwoye, Onuigbo.1993. Social issues on walls: Graffiti in university lavatories. Discourse \& Society, 4, 419-442.

[29] Oganda, H. (2015). The Language of graffiti on Public Transport Vehicles in Kenya: Issues and perspectives. International Journal of Education and Research, 3(6), 47-56.

[30] Onyango, O. (2016). The Talking Walls of Rongo University College: A Linguistic Analysis of Graffiti Use at Rongo University College. International Journal of Academic Research in Progressive Education and Development, 5(1), 1-6. 
[31] Raymonda. (2008). The Sociolinguistics study of graffiti arts used in Surakarta (Unpublished master's thesis). Muhammadiyah University, Surakarta, Indonesia.

[32] Reisner, R. (1971). Graffiti: Two thousand years of wall writing. New York: Cowles Book Company.

[33] Samuel, O. (2000). Speaking the Unspeakable: Discursive Strategies to Express Language Attitudes in Legon (Ghana) Graffiti. Research on Language and Social Interaction, 33(3), 291-319.

[34] Sheivandi, L., Taghinezhad, A., Alishavandi, A., and Ranjbar, S. (2015). Exploring Linguistic Aspects in Iranians' Graffiti. Journal of Applied Linguistics and Language Research, 2(5), 62-73.

[35] Stocker, T.L., Dutcher, L.W., Hargrove, S.M., \& Cook, E.A. (1972). Social Analysis of Graffiti. Journal of American Folklore, 85(338), 356-366.

[36] Tracy, S. (2005). The Graffiti Method. Australian Midwifery Journal, 18(3), 22-26.

[37] Trahan, A. (2011). Identity and ideology: The dialogic nature of Latrinalia. Internet Journal of Criminology, 1-9.

[38] Wardhaugh, Ronald. (2006). An Introduction to Sociolinguistics, 5th Edition. Oxford: Blackwell Publishing.

[39] Yieke, F. (2003). Graffiti: vandalism or expression academic freedom and intellectualism at universities in Kenya. Paper presented at the conference on Canonical Works and Continuing Innovation in African Arts and Humanities at the University of Ghana in Legon, Accra, September 17-19.

Mohammad Abd Alhafeez Ali Ta'amneh was born in Jordan in 1980. He got his BA. in English language and Literature from Yarmouk University in 2002 and MA. in Teaching English as a Foreign Language (TEFL) from The Hashemite University in 2005, whereas Ph.D. in English Language Curriculum and Instruction from Yarmouk University in 2012. Dr. Mohammad Ta'amneh is an Associate Professor of Teaching English as a Foreign Language (TEFL) at Taibah University. His research interests include applied linguistics, blended learning, language teaching, e-learning, and language analysis. 